\title{
THE ROLE OF PRO-INFLAMMATORY CYTOKINES IN THE GENESIS OF PHYSIOLOGICAL AND PATHOLOGICAL PREGNANCY PREDICTING
}

\author{
Oles Konovalenko ${ }^{1}$, Lubov Lapovets ${ }^{2}$ \\ ${ }^{1}$ Clinical facility Hospital in Lutsk \\ ${ }^{2}$ National Medical University in Lions
}

Konovalenko O., Lapovets L., (2014) The role of pro-inflammatory cytokines in the genesis of physiological and pathological pregnancy predicting, Health Problems of Civilization 1(8), p. 15-17

Objective: hold concentration determination and study changes in interleukin-1 (IL-1) and interleukin - 6 (IL-6) in pregnant
women outside urban areas and in pregnant women living in the city, and to predict the appearance of a possible risk of premature birth.

Material study: Were examined 40 pregnant women who make up the group of 23-27 weeks of gestation who were admitted with threatened preterm labor (20 pregnant women living in the countryside, and 20 pregnant women living in the city), as well as a control group - 20 healthy pregnant women with physiological pregnancy.

Methods: In all patients and control group was performed determining the content of IL - 1 and IL - 6 in serum by enzyme immunoassay (ELISA) using a test system»Vector-Best» (Russia) on an automatic ELISA analyzer «Triturus». Statistical analysis of data was carried out using the method of variation statistics with using STATISTICA 6 (Statsoft, USA)

The results of the study: in determining kontsentratsiyiyi proinflammatory cytokines observed increase in IL-1 and IL-6 in pregnant women living in countryside and cities in the pregnant compared with the control group of pregnant women with physiological pregnancy (probability differences $(\mathrm{p}<0,05)$ )

Conclusions: The definition and measurement of proinflammatory cytokines is an opportunity to use the test as early inflammation and mapping the degree of threat of preterm labor. The study of changes in the cytokine brings us to the pathogenic mechanisms of the transition process active infection.

Key words: Pro-inflammatory cytokines, pregnancy.

\section{Introduction}

The problems of modern obstetrics miscarriage are one of the first places as set high perinatal and infant morbidity and mortality. Despite some success rate of preterm birth does not have sustained downward trend and is $5-9 \%$. The polietiologycal process of premature births leads that every third case its reason remains unexplained (Сидельникова В.M. 2006).

According to recent years in the regulation of the immune response during pregnancy play an important role local and systemic immune process. The immune system of a woman standing on guard antigenic homeostasis is an important of adaptation, including the carrying pregnancy. Commonly role of cytokines in the regulation of embryogenesis, the formation and development of several organs, including the immune system, blood, protective responses to local and systemic level, and the processes of regeneration and tissue damage. Particularly relevant is the study of cytokine status in different forms of pathology of pregnancy because of changes in serum concentrations may be an early indicator of systemic immune disorders (Макарова 0.В.2007, ХонинаН.А.2006). The primary mediators of the interaction of immune cells of the mother and fetus are cytokines that play an important role in implantation, growth and development of the embryo (Coulam C. 2000). Cytokines - this endogenous mediators that are synthesized by almost all nuclear cells. Despite intensive research in immunology, it is not fully learned the importance of different cytokines in the genesis of physiological and pathological pregnancy. Cytokines perform regulatory role in the evaluation of the immune response. Changes in immune homeostasis are the major factor in the structure of gestational complications, the degree of severity of complications of pregnancy, predicting its course (Макарова 0.et all 2007).

\footnotetext{
Adress for correspondence: Oles Konovalenko, Clinical facility „Lutsk lying-in hoshital, Lutsk e-mail: oles.konovalenko@gmail.com, phone +38 (50) 259-60-24

Tables: 1 Figures: 0 References: 16 Full-text PDF www.hpc.edu.pl Copyright (C) Pope John Paul II State School of Higher Education In Biała Podlaska, Sidorska 95/97, 21-500 Biała Podlaska Indexation: Index Copernicus, Polish Ministry of Science and Higher Education. This is an open-access article distributed under the terms of the Creative Commons Attribution Non-commercial License (http://creativecommons.org/licenses/by-nc/3.0), which permits use, distribution, and reproduction in any medium, provided the original work is properly cited, the use is non-commercial and is otherwise in compliance with the license.
} 


\section{Objective}

To determine the concentration of interleukin-1 (IL-1) and interleukin-6 (IL-6) in pregnant women outside of urban areas and in pregnant women who live in the city. Based on these data we will try to predict the emergence of a possible risk of preterm birth.

\section{Facilities and methods}

It was examined of 40 pregnant women who make up the group of 23-27 weeks of gestation who were admitted with threatened preterm labor, and the control group - 20 healthy pregnant women with physiological pregnancy. The main group was divided into 2 subgroups: the first subgroups were 20 pregnant women living in the countryside, in the second subgroup were pregnant, living in the city. All patients performed using immunoferment analyze determination of IL - 1 and IL-6 using test system "Vector-Best" (Russia) on an automatic immunoenzymatic analyzer "TRITURUS".

Results of the research were analyzed using mathematical method - statistical treatment of data acquisition using the method of variation statistics using STATISTICA 6 (Statsoft, USA) (Боровиков В. 2001).

\section{Results and discussion}

Content of the study of cytokines in serum concentrations it was observed multidirectional changes of concentration IL-1 and IL-6 in pregnant women of the first and second subgroups of the main group, compared with the contents of cytokines in healthy pregnant (table 1).

Table 1. The level of cytokines in pregnant women according to residence area

\begin{tabular}{|c|c|c|c|}
\hline \multirow[b]{2}{*}{ Index } & \multicolumn{2}{|c|}{ The main group } & \multirow{2}{*}{$\begin{array}{l}\text { The control group } \\
\qquad(n=20)\end{array}$} \\
\hline & $\begin{array}{c}\text { First subgroup } \\
(n=20)\end{array}$ & $\begin{array}{c}\text { Second subgroup } \\
(\mathrm{n}=20)\end{array}$ & \\
\hline IL-1 (pg/ml) & $23,2 \pm 4,9^{*}$ & $17,2 \pm 7,0 * \#$ & $5,7 \pm 3,5$ \\
\hline IL-6 (pg/ml) & $177,0 \pm 79,8^{*}$ & $56,9 \pm 25,2 * \#$ & $8,4 \pm 4,9$ \\
\hline
\end{tabular}

The central mediator of local and systemic inflammatory responses is IL-1. Describing the figure, there were elevated levels of IL-1 first subgroup at 4 times $(\mathrm{p}<0,05)$, compared to the control group and at 1,3 times compared to the second subgroup $(\mathrm{p}<0,05)$. Also increase of interleukin was observed in the second subgroup relative to the control group at 3,02 times $(\mathrm{p}<0,05)$.

It is believed that IL-1 promotes the development of the fetus stimulates the proliferation of cells that form the placenta barrier. Interleukin-1 selectively activates the synthesis and secretion of steroid hormones, which affect the level of pregnancy (Matsumura T.2004). IL-1 has a feature to stimulate the synthesis of prostaglandins, triggering the mechanism of preterm birth. Increased secretion of interleukin-1 may lead to the activation of pro-inflammatory cascade that probably complicates pregnancy, leading to the initiation of childbirth. Supporting this cytokine at low levels is one of the factors affecting the preservation of pregnancy (Dinarello C.2002, Xia H.2006).

Describing the level of interleukin-6 (IL-6) which refers to the pro-inflammatory cytokines it was observed its high concentration in the study group in both subgroups. Compared with the control group IL- 6 growth in the first group is at 21 times and an increase in the second group is larger at 6, 77 times. Concentration IL- 6 in pregnant that live outside the city exceed at 3,2 times the concentration in pregnant who lives in the city. Interleukin- 6 is a major mediator of acute phase proteins. Under the influence of an infectious agent may increase the production of prostaglandins, IL-6 and the development of premature childbirth (Casart Y. 2007). There are opinions that interleukin-6 stimulates neutrophils, macrophages in the local production of pro-inflammatory cytokines that affect the maturation and opening of the cervix (Margni R. 2001). 


\section{Conclusions}

The study of cytokines in pregnancy enables to establish the extent to which central mechanisms involved in immunoregulation. Growing concentrations of interleukin-1 $(>11 \mathrm{pg} / \mathrm{ml})$ and interleukin-6 (>10 pg/ml) shows the development of the inflammatory process that can be used as an early test of inflammation and severity of the process, which can lead to premature birth.

\section{References:}

1. Боровиков В. (2001) STATISTICA: искусство анализа данных на компьютере. Для профессионалов / В. Боровиков. - С-Пб: Питер,. - 656 с.

2. Володин Н.И,.Румянцева А.Г,.Владимирская Е.Б,.Дегтярева (2001) М.В Цитокины и преждевременные роды / // Педиатрия. -. - №4. - С. 72-74.

3. Casart Y. (2007). Serum levels of interleukin-6, interleukin-1beta and human chorionic gonadotropin in preeclamptic and normal pregnancy / Y. Casart, K., Tarrazzi, M. Camejo Gynec. Endocr. - Nr 23. - P. 300-320.

4. Сидельникова В.М. А.Г.Антонов. (2006) Преждевременные роды. Недоношеный ребенок. - М.; ГЭОТАР Медиа,. -456 с.

5. Старостина Т.А..Демидова Е.А,.Анкирская А.С (2002) и др Современные вопросы патогенеза и терапии невынашивания беременности /. // Акушерство и гинекология. - № 5. - С. 59-61.

6. Степаничев М.Ю 2005. Цитокины как нейромодуляторы в центральной нервной системе / М.Ю.Степаничев. // Биохимия, - № 22: 1. - С. 5-11.

7. Сухих Г.Т,.Ванько Л.В Сухих Г.Т. Иммунология беременности /. - М: Изд-во РАМН,. - С. $248-256$.

8. Сухих Г.Т,.Ванько 2005 Л.В Сухих Г.Т. Иммунные механизмы в физиологии и патологии беременности /. // Иммунология. -. - № 9: 2. - С. 103-108.

9. Coulam C. (2000)Understanding The Immunobiology of Pregnancy and applying it to treatment of recurrent pregnancy loss. Early pregnancy / C.Coulam // Biol. Med. -. - Vol. 4, № 1. - P. 19-29

10. Dinarello C. (2002) The IL-1 family and inflammatory diseases / C.Dinarello // Clin. Exp. Rheumatol. -. - Vol. 20, № 1. - P. 170-177.

11. Лаповець Л.Є,.Луцик Б.Д,.Лебедь Г.Б,.Акімова В.М. (2008)- Львів, Посібник з лабораторної імунології. -268 c.

12. Макаров О.В,.Ковальчук Л.В,.Ганковская Л.В и др. (2007) - М: Гэотар-Медиа, Невынашивание беременности, инфекция, врожденный иммунитет. - С. 90-99.

13. Макарова О.В,Алешина В.А,.Савченко Т.Н. (2007)- М.: МЕДпрессиформ Инфекции в акушерстве и гинекологии - $420 \mathrm{c}$.

14. Margni R (2001). During pregnancy, in the context of a Th2-type cytokine profile, serum IL-6 levels might condition the quality of the synthesized antibodies / R.Margni, A.Zenclussen // Am. J. Reprod. Immunol. - Vol. 46, № 3. - P. 181-187.

15. Matsumura T., Hayashi H.,Takii T., et al. (2004) TGF- $\beta$ down-regulates IL-1, induced TLR2 expression in murine hepatocytes /. // J. Leukocyte Biol. - Vol. 75. - P. 1056-1061.

16. Xia H, Peng J.,Sun Q., et al (2006) Effects of IL-1 beta on RT1-AØRT1-DM at the maternal-fetal interface during pregnancy in rats /. // Front Biosci. -. - № 11. - P. 2868-2875.

Submitted: 05.11 .2013

Accepted: 13.12 .2013 